\title{
Development of Massage Therapy Learning Media Based on Articulate Storyline Applications
}

\author{
$1^{\text {st }}$ Ari Wibowo Kurniawan \\ Faculty of Sports Science \\ Universitas Negeri Malang \\ Malang, Indonesia \\ ari.wibowo.fik@um.ac.id
}

\author{
$2^{\text {rd }}$ Muhammad Fahmi Amiruddin \\ Faculty of Sport Science \\ Universitas Negeri Malang \\ Malang, Indonesia \\ m.f.amiruddin.24@gmail.com
}

\begin{abstract}
This research and development aims to develop massage therapy learning media based on the articulate storyline application which can later be used in learning in the PJKR FIK UM department and can make it easier for students to understand massage therapy material. The method used is the Research and Development (R\&D) approach with a development research model with the steps (1) needs analysis, (2) doing product design (design), (3) product development (development), (4) implementation or (implementation), and (5) product evaluation (evaluation). The test results of the whole product involved 60 students of PJKR FIK UM. Based on the results of data analysis obtained from trials with aspects of ease, clarity, attractiveness, suitability, and usefulness, the average result is $95 \%$ in small group trials with 10 students as subjects and $90 \%$ in large group trials with $\mathbf{5 0}$ students as subjects. Based on the results of data analysis, it can be concluded that the product of developing massage therapy learning media based on the articulate storyline application can be said to be suitable for use as massage therapy learning media for students majoring in PJKR FIK UM.
\end{abstract}

Keywords - learning media, therapy massage, articulate storyline application.

\section{INTRODUCTION}

Advances in Science and Technology (IPTEK) have affected all spheres of life. Work that was usually done manually can now be done using machines. Technological advances with the existence of this digital era allow automation in almost all fields (Tjandrawinata \& Medica, 2016). This results in humans being required to think ahead in various ways, so that later they are not considered to be left behind. Science and Technology (IPTEK) is certainly very influential on the world of education and the learning process. For this reason, an educator is expected to be able to develop and implement good learning strategies. Through advances in the field of science and technology, educators can use a variety of media in learning. In the teaching and learning process, the media used or used by teachers or educators must be in accordance with the learning objectives that have been set, so that later they are able to stimulate and also grow the interest of students or students in the learning process (Wena, 2013). Thus, the teaching materials or learning resources used must be adapted to the needs and objectives of learning, so that later it will facilitate, expedite, and streamline the teaching and learning process, and can make the teaching and learning process more interesting. Students are more interested in everything that smells of technology ranging from games, information, services, and so on (Nurpitasari, Aji, \& Kurniawan, 2018).

The process of learning or teaching and learning is a process in which there is interaction between teachers or educators with students or students. Learning is a learning activity which, among others, is carried out by teachers in conditioning someone to learn, the process of interaction between teachers and students, both direct interactions such as face-to-face activities or indirectly or online, namely by using various interesting learning media for students. Asmadawati, 2014). The teacher or educator is a very important component of the education staff, who has the task of carrying out learning or teaching and learning (Wena, 2013). Teachers or educators play a very important role in cultural change through school settings, especially in carrying out interactions between students and teaching materials or learning resources that will later aim to achieve the desired achievements of students. So, in the learning process, educators and students are important and inseparable members, between educators and students there must be good and good interactions so that teaching and learning objectives can be achieved optimally.

Learning is generally carried out starting from the elementary school level (elementary school), junior high school level (junior high school), high school level (high school), to PT (college) in which there is a curriculum. The curriculum is a collection of competency standards for subjects or fields of study (Toenlioe, 2017). For example, the competency standards for science, social studies, mathematics, PJOK, and language. The same is the case with the curriculum in universities, which is the same as a collection of courses. The curriculum contained in higher education institutions (PT), especially in the PJKR FIK UM study program, contains theoretical and practical courses. One of the practical courses is massage. With the practice of massage courses, educators or lecturers will find 
and choose the appropriate method. Apart from the selection of learning methods, the selection of learning media also serves as an effort to achieve learning objectives. This is important, because not all PJKR FIK UM students know about massage Massage therapy is one of the treatments for injuries, while treatment after injury can be done with exercise therapy so that the injury condition recovers perfectly (Harsanti \& Graha, 2014). Massage can be defined as the systematic manipulation of the body's soft tissues for pain relief or other therapeutic purposes. Massage is the systematic manipulation of the soft tissues of the body with rhythmic pressure and stroking, preventing, developing, maintaining, rehabilitating, or enhancing physical functioning or relieving pain (Bervoets, Luijsterburg, Alessie, Buijs, \& Verhagen, 2015). Massage is a manipulation that aims to relax tense muscles, improve blood and lymph circulation.

Learning media are everything that is used as communication or to convey messages, information / learning materials so as to stimulate the attention, interests, thoughts and feelings of students in learning activities to achieve certain learning goals (Kurniawan, 2019). According to Mukhlis, Kurniawan, \& Kurniawan (2020) Learning using interactive multimedia can make students more active to learn with high motivation because of their interest in learning media that are able to display text, images, videos, sounds and animations.

The benefits of learning media according to (Dwijayani, 2019) are twofold, first, as a guide for teachers to achieve learning goals and can explain learning materials in a systematic order and attractive presentation, second, they can increase students' motivation and interest in learning so that students can think and analyze the material provided by the teacher well in a pleasant learning situation.

In today's era, of course, education must keep up with the times where technology is developing very rapidly. One of them is in the field of education. Nowadays, there are many learning media that teachers can use, such as Articulate storyline applications that can create learning media in the form of html5, android, flv and links. How to use a very easy to understand combines images, animations, sound and video in one media that runs. Articulate Storyline is a software or software that has a function as a medium in interactive learning. This software can be used in presenting information according to its purpose. By using Articulate Storyline, the presentation will be much more attractive so that the participants who take part in the presentation will find it easier to understand and avoid boredom (Pratama, 2018). Articulate Storyline is a piece of software that can be used to create presentations. Articulate Storyline have the same functionality as Microsoft PowerPoint, yet articulate storyline has several advantages compared with microsoft power point so as to produce a presentation more interesting and creative. Articulate Storyline learning media is one of the learning media that is intentionally made to package a lesson (Arwanda, Irianto, \& Andriani, 2020). The Articulate Storyline application is an e-learning tool (software) that serves to help build interactive (learning) content (Darnawati, Batia, Irawaty, \& Salim, 2019). Articulate Storyline-based interactive learning media is declared very suitable to be used to support teaching and learning activities in the classroom as well as as independent learning (Yumimi \& Rakhmawati, 2015).
In an effort to find out current needs, researchers use a needs analysis instrument in the form of a questionnaire instrument. Questionnaire is a question (statement) given by the researcher for the respondent to fill out, with the intention of asking for answers or respondents' opinions about the objects asked by the researcher (Arikunto, 2017: 63).

Based on the results of the distribution of the needs analysis instrument in the form of a questionnaire given to all PJKR FIK UM classes, there were 130 returned questionnaires. The results of the needs analysis of 130 PJKR FIK UM students who took massage courses got the results (1) $98 \%$ of students stated that they received massage therapy material, (2) $85 \%$ of students needed new learning media in massage therapy learning, (3) $98 \%$ of students stated that it is necessary to develop teaching materials in massage therapy learning.

\section{METHOD}

Based on the background described above, thus in this study using development research. This research on the development of learning media or massage therapy learning is compatible with the type of development research model developed by Lee \& Owen by using the following stages:

1) analysis, 2) design, 3) development, 4) implementation, 5 ) evaluation.

If viewed from the research objectives, this type of development research uses qualitative and quantitative research types. The variables used in this research are massage therapy learning media based on the articulate storyline application. In an effort to complete the desired data, the researchers took data using a questionnaire technique. In collecting data, this study uses non-test.

This research uses quantitative and qualitative data types. Quantitative data can be obtained from the results of filling out questionnaires carried out on needs analysis, small group trials and also large groups in the form of numbers. While qualitative data obtained from criticism, suggestions, and responses from validators.

To collect data, this study uses a measurement technique using a Likert scale. The purpose of using the Likert scale is to measure the attitudes, opinions and perceptions of a person or group of people about social phenomena (Sugiyono, 2015). In the Likert scale instrument there are levels of answers consisting of very positive and very negative. For the purposes of quantitative data analysis, answers can be assigned a predetermined score, namely one (1), two (2), three (3) and four (4).

Table 1. Rating Scale for Positive Statements (Sugiyono, 2015).

\begin{tabular}{clcc}
\hline No. & Information & Answer & $\begin{array}{c}\text { Positive } \\
\text { Score }\end{array}$ \\
\hline 1. & Strongly agree & A & 4 \\
2. & Agree & B & 3 \\
3. & Doubtful & C & 2 \\
4. & Do not agree & D & 1 \\
\hline
\end{tabular}


The formula for processing data in the form of percentage quantitative descriptive analysis according to the following:

$$
\mathrm{V}=\frac{\mathrm{TSEV}}{\mathrm{S}-\max } \times 100 \%
$$

\section{Information:}

$\begin{array}{ll}\mathrm{V} & \text { : Validity } \\ \text { TSEV } & : \text { Total empirical validator score } \\ \text { S-max } & : \text { Maximum expected score } \\ 100 \% & : \text { Number constant }\end{array}$

In the process of concluding the data from the results of the percentage analysis, it can be distinguished according to the percentage that has been obtained. the percentage difference is as follows:

Table 2. Product Quality Criteria (Irawan \& Japarianto, 2013)

\begin{tabular}{ccc}
\hline Criteria & Information & Mean \\
\hline $75.01 \%-$ & Very Valid & Used without revision \\
$100.00 \%$ & & \\
$50.01 \%-$ & Quite Valid & Used with minor \\
$75.00 \%$ & & revisions \\
$25.01 \%-$ & Invalid & Can not be used \\
$50.00 \%$ & & \\
$00.00 \%-$ & Very Invalid & Forbidden to use \\
$25.00 \%$ & & \\
\hline
\end{tabular}

III. Results and Discussion

Research

Table 3 Results of Media Expert Data Analysis

\begin{tabular}{|c|c|c|c|}
\hline No & Aspect & Appropriateness & Category \\
\hline 1 & Clarity & $95 \%$ & Very Valid \\
\hline 2 & Suitability & $98 \%$ & Very Valid \\
\hline 3 & Attractiveness & $97 \%$ & Very Valid \\
\hline 4 & Convenience & $95 \%$ & Very Valid \\
\hline 5 & Accuracy & $100 \%$ & Very Valid \\
\hline \multirow[t]{2}{*}{6} & Completeness & $100 \%$ & Very Valid \\
\hline & Average & $97 \%$ & Very Valid \\
\hline \multicolumn{4}{|c|}{$\begin{array}{l}\text { Based on the results of data analysis obtained } \\
\text { from media experts with a percentage of } 97 \% \text {, these results } \\
\text { were obtained based on certain aspects and then converted } \\
\text { based on the feasibility classification table showing that the } \\
\text { product development of the articulate } \\
\text { storyline application in massage therapy learning has met } \\
\text { the very valid criteria and is feasible to use. }\end{array}$} \\
\hline \multicolumn{4}{|c|}{ Table 4 Results of Learning Expert Data Analysis } \\
\hline No & Aspect & Appropriateness & Category \\
\hline 1 & Clarity & $85 \%$ & Very Valid \\
\hline 2 & Convenience & $100 \%$ & Very Valid \\
\hline
\end{tabular}

\begin{tabular}{cccc}
3 & Accuracy & $100 \%$ & Very Valid \\
\hline Average & $\mathbf{9 5 \%}$ & Very Valid
\end{tabular}

Based on the results of data analysis obtained from learning experts with a percentage of $95 \%$, these results were obtained based on certain aspects and then converted based on the feasibility classification table showing that the product development of the articulate storyline application in massage therapy learning has met the very valid criteria and is feasible to use.

Table 5 Results of Data Analysis of Massage Therapists

\begin{tabular}{cccc}
\hline No & Aspect & Appropriateness & Category \\
\hline 1 & Accuracy & $88 \%$ & Very Valid \\
\hline 2 & Convenience & $100 \%$ & Very Valid \\
\hline 3 & Suitability & $100 \%$ & Very Valid \\
\hline & Average & $\mathbf{9 6 \%}$ & Very Valid \\
\hline
\end{tabular}

Based on the results of data analysis obtained from massage therapists with a percentage of $96 \%$, these results were obtained based on certain aspects and then converted based on the feasibility classification table showing that the product development of the articulate storyline application in massage therapy learning has met the very valid criteria and is feasible to use.

Table 6 Results from Trial (Small Group)

\begin{tabular}{cccc}
\hline No. & Aspect & \% & Category \\
\hline 1 & Clarity & 94 & Very Valid \\
2 & Suitability & 96 & Very Valid \\
3 & Attractiveness & 94 & Very Valid \\
4 & Convenience & 94 & Very Valid \\
5 & Utility & 99 & Very Valid \\
\hline & Average & $\mathbf{9 5}$ & Very Valid \\
\hline
\end{tabular}

Based on the results of the analysis of data obtained from a trial (small group) with a subject of 10 PJKR FIK UM students, the percentage result was $95 \%$. These results were obtained based on several aspects which later the results would be converted based on the feasibility classification table stating that the product development of the articulate storyline application in massage therapy learning can be said to be feasible to use and is included in very valid criteria.

Table 7 Trial Results (Large group)

\begin{tabular}{|c|c|c|c|}
\hline No. & Aspect & $\%$ & Category \\
\hline 1 & Clarity & 89 & Very Valid \\
\hline 2 & Suitability & 90 & Very Valid \\
\hline 3 & attractiveness & 89 & Very Valid \\
\hline 4 & Convenience & 91 & Very Valid \\
\hline 5. & Utility & 93 & Very Valid \\
\hline \multicolumn{2}{|r|}{ Average } & 90 & Very Valid \\
\hline
\end{tabular}

Based on the results of the analysis of the data obtained from the trial (large group) with a subject of 50 PJKR FIK UM students, the percentage result was $90 \%$. These results were obtained based on several aspects which later were converted based on the feasibility 
classification table stating that the product development of the articulate storyline application in massage therapy learning can be said to be feasible to use and can be classified in very valid criteria.

\section{Discussion}

Research and development aims to develop a massage therapy learning media based on the articulate storyline application. The process of learning or teaching and learning is a deliberate systematic effort made to cause or grow the learning process in a person or individual. In an effort to achieve learning objectives, of course, there are several aspects that support learning such as infrastructure, learning media and an educator who is competent in their field. A competent educator still needs suitable learning methods and media so that the delivery of learning and learning materials will be faster and easier for students to understand or accept. Among other things, learning media that can be used in the massage therapy learning process is to use the articulate storyline application. Articulate Storyline is a software or software that functions as an interactive learning media which includes features such as text, audio and video that are easy to use. Articulate Storyline is a software made by Global Incorporation launched in 2014 which is used to create interactive elearning learning (Nuraini \& Mintowati, 2021). By using Articulate Storyline, the presentation will be much more attractive so that the participants who attend the presentation will be easier to understand and avoid boredom.

This research produces a product in the form of developing massage therapy media based on the articulate storyline application. Product development of instructional media applications based massage therapy articulate storyline has the advantage that this product can diaskses anytime and anywhere without the use of the Internet data network, besides in the development of products available text, audio, and video about massage therapy. So with this development product, it is hoped that it can help in increasing the understanding of PJKR FIK UM students.

The product development of massage therapy learning media based on the articulate storyline application also has limitations, including: 1) product development based on the articulate storyline application is limited to massage therapy material, 2) product development based on the articulate storyline application is only for PJKR FIK UM students.

The product developed by researchers is in the form of massage therapy learning media based on the articulate storyline application for PJKR FIK UM students. The product developed is a media product as a means used by lecturers in the learning process, the delivery of subject matter to students is concise in an attractive manner so that it can increase student learning interest. The media developed is based on an acrticulate storyline. Articulate storyline is useful in the learning process because it can convey material easily.

The results of the validation of learning experts related to the development of massage therapy learning media products based on the articulate storyline application were obtained in the form of evaluation suggestions for learning experts, namely revamping the background, buttons, icons, and videos to make them more interesting. Suggestions and inputs have been improved by researchers on product development in the form of an articulate storyline.

The articulate storyline media development product has been validated by media experts with no revisions or suggestions. Learning activities that use appropriate media, such as utilizing articulate storylines in the teaching and learning process will create a fun and not boring atmosphere so that the learning process will focus on interesting learning media and make learning activities effective and efficient. Other findings also show that the development of interactive media created in learning can be one way to foster enthusiasm for learning and become a reference for additional learning resources (Rahman, Kurniawan, \& Heynoek, 2020).

Based on the test results of the entire product involving 60 PJKR FIK UM students. The results of the study show that the product is included in the very valid category with $95 \%$ percentage results in small group trials with a total of 10 activity participants and $90 \%$ percentage in large group trials with a total of 50 activity participants. So it was concluded that the product of developing massage therapy learning media based on the articulate storyline application had very valid criteria and was suitable for use in learning activities. This shows that learning using articulate storylines is valid and can be used as a tool in the massage therapy learning process. The results of the product development of massage therapy learning media using articulate storylines have been validated and tested and revised several times so that they have several advantages (1) The product is made with an articulate storyline application that can be used offline. (2) Contains teaching materials in the form of massage therapy videos that are packaged in an attractive way. (3) This development product can be used by lecturers as a means in the current online learning process.

It is hoped that after the development of massage therapy learning media products, it will be more varied and more modern, thereby influencing student interest and increasing educators' knowledge in the field of technology that is useful for teachers in the implementation of massage therapy learning.

\section{CONCLUSION}

Based on the results of the data analysis that has been carried out, it can be stated that the product development of the articulate storyline application in massage therapy learning can be used as a reference or source of independent learning for students majoring in PJKR FIK UM. By using this development product, it will certainly make it easier for PJKR FIK UM students in learning activities and make it easier to obtain information, this is obtained based on studies of experts consisting of massage therapists, learning experts, and media experts who are assessed based on several aspects which include: suitability, accuracy, clarity, convenience, and attractiveness. In addition, it can also be seen through the results of data analysis obtained from needs analysis, small group trials, and large group trials. 


\section{REFERENCES}

[1] Arikunto, S. (2017 ). Development of Research Instruments and Program Assessment . Yogyakarta: Student Library.

[2] Arwanda, P., Irianto, S., \& Andriani, A. (2020). Development of Articulate Storyline Learning Media Curriculum 2013 Based on Competency of 21 st Century Learners Theme 7 Grade IV Elementary School. Al-Madrasah: Journal of Madrasah Ibtidaiyah Education, 4(2), 193. https://doi.org/10.35931/am.v4i2.331

[3] Asmadawati. (2014). Teaching Planning. Darul Ilmi, 02(01), 1-13.

[4] Bervoets, DC, Luijsterburg, PAJ, Alessie, JJN, Buijs, MJ, \& Verhagen, AP (2015). Massage therapy has short-term benefits for people with common musculoskeletal disorders compared to no treatment: A systematic review. Journal of Physiotherapy, 61(3), 106-116. https://doi.org/10.1016/j.jphys.2015.05.018

[5] Darnawati, Batia, L., Irawaty, \& Salim. (2019 ). Teacher Empowerment Through the Development of Interactive Learning Multimedia With Articulate Storyline Application . Journal of Community Service, 1(1).

[6] Dwijayani, NM (2019). Development of circle learning media to improve student learning outcomes . Journal of Physics: Conference Series, 1321(2), 17187. https://doi.org/10.1088/17426596/1321/2/022099

[7] Harsanti, S., \& Graha, AS (2014 ). The Effectiveness of Massage Therapy and Loading Exercise Therapy in Increasing Range of Movement After Minor Ankle Injury . JOURNAL MEDIKORA Vol. XIII No. 1 October 2014 EFFECTIVENESS, XIII(1).

[8] Irawan, D., \& Japarianto, E. (2013). Analysis of the Effect of Product Quality on Loyalty through Satisfaction as an Intervening Variable for Customers of Por Kee Restaurant Surabaya . Journal of Marketing Management.

[9] Kurniawan, AW (2019). Multimedia-Based Learning Model for Gymnastics Skills . 7(Icssh 2018), 3336. https://doi.org/10.2991/icssh-18.2019.8

[10] Mukhlis, NA, Kurniawan, AW, \& Kurniawan, R. (2020). Development of Physical Fitness Media Elements of Interactive Multimedia-Based Strength . Sport Science and Health, 2(11), 566-581.

[11] Nuraini, DV, \& Mintowati. (2021 ). Development of Articulate Storyline-Based Interactive Multimedia for Learning to Write Poetry for Class X Students of Sman 3 Ponorogo . 8(1), 1-9.

[12] Nurpitasari, E., Aji, BS, \& Kurniawan, SJ (2018). Development of Technological Competencies and the Role of Counselors in Dealing with Students in the Era of Disruption. 10-14.

[13] Primary, RA (2018). Learning Media Based On Articulate Storyline 2 On Drawing Function Graphs Lesson In Patra Dharma 2 Junior High School Balikpapan Learning Media Based On Articulate Storyline 2 On Drawing Function Graphs Lesson In Patra Dharma 2 Junior High School Balikpapan Introduction Mathematics. 7(1), 19-35.

[14] Purnama, DA, Munir, M., Azwar, E., \& Tarigan, MRM (2019). The Effect of Active Debate Model on Student
Learning Outcomes on Ecosystem Materials in Class X Madrasah Aliyah Private Project Univa Medan . Journal of Biolocus, 2(1), 5. Retrieved from

[15] Puspitasari, P., Sari, P., Putri, J., \& Wuryani, W. (2018). The Influence of the Use of Learning Media on the Learning Motivation of IKIP Siliwangi Students. Parole: Journal of Indonesian Language and Literature Education, 1(2), 227-232.

[16] Rahman, Z., Kurniawan, AW, \& Heynoek, FP (2020). Development of Physical Fitness Learning Elements of Speed Based on Interactive Multimedia . Sport Science and Health, 2(1), 78-92. Retrieved from http://journal2.um.ac.id/index.php/jfik/article/view/1 $1692 / 5123$

[17] Sugiyono. (2015). Educational Research Methods . Bandung: Alphabeta.

[18] Toenlioe, AJ (2017). Curriculum Development Theory, Critical Notes, and Guidelines. Bandung: PT Refika Aditama.

[19] Wena, M. (2013). Contemporary Innovative Learning Strategy (8th). Jakarta: PT Bumi Aksara.

[20] Yumimi, S., \& Rakhmawati, L. (2015). Development of Articulate Storyline-Based Interactive Learning Media in Basic Electronics Engineering Courses at Smk Negeri 1 Jetis Mojokerto. Journal of Electrical Engineering Education, 4(3), 845-849. 